\title{
PENINGKATAN KETERAMPILAN MENULIS CERPEN MELALUI \\ MEDIA "ELEGI ESOK PAGI" KARYA EBID G.ADE SISWA KELAS XI SMA SWASTA NASIONAL NAMOTRASI \\ TAHUN PELAJARAN 2018/2019
}

\author{
Sri Ulina Beru Ginting \\ Linaginting31@gmail.com \\ STKIP Budidaya Binjai
}

\begin{abstract}
ABSTRAK
Penelitian ini bertujuan untuk mendeskripsikan peningkatan kemampuan menulis cerpen Siswa Kelas XI SMA Swasta Nasional Namotrasi dalam pembelajaran bahasa dan sastra Indonesia melalui penggunaan media lagu Elegi Esok Pagi . Penelitian ini diadakan berdasarkan adanya permasalahan dalam pembelajaran menulis cerpen. Kemampuan menulis cerpen siswa Kelas XI SMA Swasta Nasional Namotrasi masih tergolong kurang. Sasaran yang dikenai tindakan adalah Siswa Kelas XI SMA Swasta Nasional Namotrasi Tahun Pelajaran 2018/2019.

Jenis penelitian yang digunakan adalah Penelitian Tindakan Kelas ( PTK ). Metode yang digunakan adalah metode diskusi. Prosedur pelaksanaan tindakan dan implementasi di lokasi terbagi dalam dua siklus. Setiap siklus terdiri dari empat tahap yaitu: Perencanaan (planning), pelaksanaan tindakan (acting), observasi (observing) dan refleksi ( reflecting). Penelitian ini dilakukan secara kolaboratif antara peneliti dengan guru Bahasa Indonesia.

Hasil penelitian ini menunjukkan bahwa penggunaan media lagu Elegi Esok Pagi ciptaan Ebid G.Ade dalam pembelajaran menulis cerpen mampu meningkatkan kemampuan menulis siswa. Kemampuan rata-rata siswa dalam menulis cerpen sebelum adanya implementasi tindakan berkategori kurang. Namun setelah implementasi tindakan selama dua siklus, kemampuan rata-rata siswa dalam menulis cerpen menjadi berkategori baik. Hal ini berdasarkan hasil tes siswa dari pretes dengan nilai rata-rata hitung sebesar 33.8 meningkat di siklus I menjadi 58.8 dan pada akhir siklus II nilai rata-rata hitung kembali meningkat menjadi 88.2. Jadi kemampuan menulis siswa dari pretes sampai siklus II mengalami peningkatan sebesar 54,4.
\end{abstract}

Kata kunci : Menulis, cerpen, elegi esok pagi 


\section{PENDAHULUAN}

\section{A. Latar Belakang Masalah}

Keterampilan berbahasa sangat dibutuhkan oleh siswa. Keterampilan berbahasa dibagi 4 yaitu keterampilan menulis, membaca, menyimak dan berbicara. Keterampilan menulis merupakan proses belajar yang memerlukan ketekunan berlatih, agar keterampilan menulis lebih meningkat.

Media yang digunakan dalam pembelajaran menulis cerpen yaitu lagu Elegi Esok Pagi , Karya Ebid.G.Ade. Lagu merupakan sebuah naskah yang berisi lirik lagu dan rangkaian kata yang merupakan ungkapan pikiran dan perasaan penyair.

\section{B. Identifikasi Masalah}

Permasalahan yang akan diteliti dalam penelitian ini adalah:

1. Banyak siswa yang tidak tekun dalam menulis.

2. Siswa tidak mampu menulis cerpen.

3. Masih ada siswa yang tidak mengerti cerpen.

4. Cara mengajar membuat siswa manjadi bosan. Sehingga Sulit mempertahankan konsentrasi siswa.

\section{Pembatasan Masalah}

permasalahan penelitian ini hanya dibatasi seputar:

1. Penggunan media lagu dalam meningkatkan hasil belajar menulis cerpen siswa kelas XI SMA Swasta Nasional Namotrasi Tahun Pelajaran 2018/2019,

2. Besarnya peningkatan media lagu dalam meningkatkan hasil belajar menulis cerpen siswa kelas siswa kelas XI SMA Swasta Nasional Namotrasi Tahun Pelajaran 2018/2019,

\section{Rumusan Masalah}

Sesuai dengan judul skripsi ini, maka masalah dalam penelitian ini dapat dirumuskan sebagai berikut:
1.Apakah media lagu dapat meningkatkan hasil belajar menulis cerpen siswa kelas siswa kelas XI SMA Swasta Nasional Namotrasi Tahun Pelajaran 2018/2019,

2.Seberapa besar media lagu dapat meningkatkan hasil belajar menulis cerpen siswa kelas siswa kelas XI SMA Swasta Nasional Namotrasi Tahun Pelajaran 2018/2019,

\section{E. Tujuan Penelitian}

Adapun tujuan dari penelitian adalah sebagai berikut:

1. Untuk mengetahui penggunaan media lagu dalam pembelajaran menulis cerpen,

2. Untuk mengetahui besarnya peningkatan.

\section{F. Manfaat Penenlitian}

1. Secara teoretis, penelitian ini diharapkan dapat mendukung teori tentang kemampuan menulis cerpen melalui media lagu yang sangat bermanfaat bagi perkembangan ilmu pengetahuan, khususnya dalam pengajaran Bahasa Indonesia.

2. Secara Praktis, hasil penelitian ini di harapkan akan bermanfaat sebagai berikut:

a. Bagi Siswa, hasil penelitian ini diharapkan dapat menjadi motivasi untuk meningkatkan kemampuan mereka dalam menulis. Selain itu, tindakan yang diterapkan guru dikelas dapat membantu siswa dalam mengatasi kesulitan belajar menulis cerpen sehingga keterampilan menulis cerpen mereka meningkat.

b. Bagi Guru, Bahasa Indonesia kelas XI SMA Swasta Nasional Namotrasi , hasil penelitian ini diharapkan dapat mengembangkan kemampuan guru dalam menghadapi permasalahan dalam pembelajaran dikelas terutama permasalahan yang berkaitan dengan kesulitan menulis 
dan sebagai bekal bagi peneliti untuk mempersiapkan menjadi guru yang mampu meningkatkan kualitas pembelajaran.

c. Bagi Lembaga Pendidikan, memberikan kesempatan dalam memperluas wawasan, sebagai sumbangan pemikiran bagi dunia pendidikan khususnya studi Bahasa Indonesia. Karena hasil penelitian ini dapat digunakan sebagai pengembangan proses pengajaran Bahasa Indonesia dalam meningkatkan keterampilan menulis cerpen.

\section{A. Kerangka Teoretis \\ 1. Menulis \\ a. Defenisi Menulis}

Menulis adalah salah satu keterampilan berbahasa yang sangat dibutuhkan oleh siswa. Menulis merupakan kegiatan mengubah bunyi menjadi tulisan sebagai upaya untuk mengungkapkan gagasan menjadi bahasa tulis memerlukan sejumlah potensi pendukung yang untuk mencapainya dibutuhkan kesungguhan, kemauan keras, bahkan belajar dengan sungguh-sungguh.

\section{b. Ciri-ciri Menulis}

Adapun ciri-ciri tulisan yang baik menurut Mc. Mahan dan Day dalam Tarigan sebagai berikut:

1.Jujur

2. Jelas

3. Singkat

4. Usahakan keanekaragaman

\section{c. Fungsi Menulis}

Ada beberapa fungsi menulis menurut para ahli antara lain;

Fungsi menulis menurut Tarigan sebagai berikut:

1. Menulis sangat penting bagi pendidikan karena memudahkan para pelajar berpikir.

2. Dapat menolong penulis untuk berpikir secara kritis.

\section{d. Tujuan Menulis}

Tujuan menulis adalah untuk menjelaskan suatu karya imajinasi serta jati diri seorang penulis, dan dapat dipahami oleh para pembaca pada umumnya dengan bahasa yang lugas.

\section{Cerpen}

\section{a. Defenisi Cerpen}

Dalam sastra dikenal dengan tiga macam bentuk, yaitu puisi, prosa, dan drama. Bentuk prosa terdiri dari beracam-macam jenis, salah satu prosa adalah cerpen. Sesuai dengan namanya cerpen adalah cerita pendek, tetapi panjang pendek ukuran fisiknya tidak jadi ukuran mutlak. Tidak ditentukan cerpen harus sekian halaman atau sekian kata, walaupun cerpen mempunyai kecenderungan untuk berukuran pendek.

\section{b. Ciri-ciri Cerpen}

ciri-ciri khas sebuah cerita pendek beserta dengan pendapat para ahli sebagai berikut:

1. Menurut Tarigan ciri-ciri cerpen sebagai berikut:

a. Ciri-ciri utama cerita pendek adalah: singkat, padu, dan intensif

b. Unsur-unsur cerita pendek adalah: adegan, tokoh, dan gerak.

c. cerita panjngnya sekitar 5000 kata/kira-kira 17 halaman spasi rangkap yang terpusat dan lengkap pada dirinya sendiri.

\section{Media}

\section{a. Defenisi Media}

Kata media berasal dari bahasa latin medius yang secara harfiah berarti tengah, perantara atau pengantar. Menurut Gerlach dan Elly yang mengatakan bahwa, "Media apabila dipahami secara garis besar adalah manusia, materi atau kejadian yang membangun kondisi yang membuat siswa mampu memperoleh pengetahua, keterampilan atau sikap.

\section{b. Ciri-ciri Media Pendidikan}

Kemudian Gerlach dan Elly (dalam Arsyad) mengemukakan tiga ciri fiksatif, ciri manipulatif dan ciri distributif yang merupakan petunjuk mengapa media digunakan dan apa-apa saja yang dapat dilakukan oleh media yang mungkin gurutidak mampu (atau kurang efesien) melakukannya.

\section{c. Fungsi Media Pendidikan}

Selain ciri-ciri media, di dalam dunia pendidikan media memiliki fungsi yang dapat menunjang tercapainya suatu tujuan pendidikan. 
Fungsi media khususnya media audio atau lagu dalam dunia pendidikan adalah untuk mempermudah siswa dalam mengungkapkan ide-ide ataupun pikiran serta daya imajinasi yang muncul akibat adanya kreativitas yang dimiliki oleh peserta didik dalam bentuk lisan maupun tulisan.

\section{d. Jenis Media Pendidikan}

Sadiman mengklasifikasikan media pembelajaran menjadi beberapa kelompok seperti berikut:

\section{Media Grafis}

Media grafis termasuk media visual sebagaimana halnya media lain, media grafis berfungsi untuk menyalurkan pesan dari sumber ke penerima pesan.

\section{Media Audio}

Berbeda dengan media grafis, media audio berkaitan dengan indra pendengaran.

\section{Media Proyeksi Diam}

Media proyeksi diam hampir sama dengan media grafik, tetapi dalam media proyeksi diam, pesan yang hendak disampaikan harus diproyeksi dengan menggunakan proyektor agar dapat diterima oleh penerima pesan.

\section{Lagu}

\section{a. Defenisi Lagu}

Dalam KBBI lagu adalah ragam suara yang berirama dalam bercakap, bernyanyi, membaca. Sedangkan didalam Ensiklopedia, lagu adalah suatu kesatuan musik yang terdiri atas susunan berbagai nada yang berurutan..

Di dalam Ensiklopedia Indonesia sebuah lagu terdiri dari beberapa unsur, yaitu:
1. Melodi
2. Lirik
3. Aransemen
4. Notasi

\section{Lagu sebagai Media Pembelajaran}

Adapun media pembelajaran yang digunakan dalam menulis cerpen adalah Lagu
Elegi Esok Pagi Karya Ebid G.Ade sebagai berikut:

Ijinkanlah kukecup keningmu

Bukan hanya ada didalam angan

Esok pagi kau buka jendela

Kan kau dapati seikat kembang merah

Engkau tau aku mulai bosan

Bercumbu dengan baying-bayang

Bantulah aku temukan diri

Menyambut pagi membuang sepi

Ijinkalah aku kenang sejenak perjalanan oh..oh..oh

Dan biarkan kumengerti

Apa yang tersimpan dimatamu oh..oh..oh

Barangkali ditengah telaga

Ada tersimpan butiran cinta

Dan semoga kerinduan ini

Bukan jadi mimpi diatas mimpi

Ijinkanlah aku rindu pada hitam rambutmu oh..oh..oh

Dan biarkan kubernyanyi

Demi hati yang risau ini oh..oh..oh...

\section{Keunggulan dan Kelemahan Media Lagu}

1. Adapun keunggulan dari media lagu menurut Arsyad adalah sebagai berikut,

a. Merupakan peralatan yang sangat murah dan lumrah sehingga mudah dijangkau oleh masyarakat

b. Rekaman dapat digandakan untuk keperluan perorangan sehingga isi pesan dapat berada ditempat secara bersamaan

c. Merekam peristiwa atau isi pelajaran untuk digunakan kemudian

2. Adapun kelemahan dari media lagu adalah sebagai berikut,

Dalam suatu rekaman sulit menemukan lokasi suatu pesan atau informasi, jika pesan atau informsi tersebut berada ditengah-tengah pita, apalagi jika radio, tape tidak memiliki angka-angka penentuan putaran

Kecepatan rekaman dan pengaturan trek yangbermacam-macam menimbulkan kesulitan 
untuk memainkan kembali rekaman yang direkam pada suatu mesin perekam yang direkam pada suatu mesin perekam yang berbeda.

\section{B. Kerangka Konseptual}

Cerpen adalah cerita pendek yang habis dibaca dalam sekali duduk, yang panjangnya tidak seperti Novel.

Lagu adalah ragam suara yang berirama dalam bercakap, bernyanyian yang merupakan kesatuan musik yang terdiri atas susunan berbagai nada yang berurutan.

Media lagu berkaitan dengan indra pendengaran. Media lagu merupakan salah satu strategi belajar mengajar, dimana siswa di dalam kelas dipandang sebagai suatu siswa individu selalu harus siap dalam memecahkan masalah atau melaksanakan tugas tertentu dan berusaha mencapai tujuan pengajaran yang telah ditentukan guru.

\section{Pertanyaan Penelitian}

Pertanyaan yang diajukan dalam penelitian ini adalah "apakah dengan menggunakan Media Lagu "Bunda" ciptaan Melly Goeslow dapat meningkatkan kemampuan menulis cerpen pada mata pelajaran Bahasa Indonesia di Kelas VIII MTS TI Hinai Kiri?"

\section{METODOLOGI PENELITIAN}

\section{A. Lokasi dan Waktu Penelitian \\ 1. Lokasi penelitian}

Penelitian ini bertempat di MTS TI Hinai

Kiri Tahun pelajaran 2016/2017 tepatya dilokal Kelas VIII-2.

\section{Waktu Penelitian}

Adapun rencana pelaksanaan penelitian ini pada semester ganjil pada tahun pelajaran 2016/2017.

\section{B. Subjek dan Objek Penelitian \\ 1. Subjek Penelitian}

Subjek penelitian ini adalah siswa-siswi Kelas VIII-2 MTS TI Hinai Kiri Tahun Pelajaran 2016/2017 yang berjumlah 34 orang.

\section{Objek Penelitian}

Objek penelitian ini adalah tindakan sebagai upaya meningkatkan keterampilan menulis cerpen dengan menggunakan Media Lagu pada mata pelajaran Bahasa Indonesia.

\section{Metode Penelitian}

Penelitian ini merupakan penelitian tindakan kelas (action research), karena penelitian dilakukan untuk memecahkan masalah pembelajaran di kelas.

\section{Rancangan Penelitian}

Rancangan/rencana awal, sebelum mengadakan penelitian, peneliti menyusun rumusan masalah, tujuan dan membuat rencana tindakan, termasuk di dalamnya instrumen penelitian dan perangkat pembelajaran.

\section{E. Prosedur Penelitian}

Menurut prosedur penelitian tindakan kelas maka, penelitian ini dilaksanakan dalam bentuk siklus dengan empat tahapan yaitu: perencanaan (planning), tindakan (action), pengamatan (observing), dan refleksi (reflekting).

\section{F. Instrumen Penelitian}

Instrumen penelitian adalah alat yang di pakai untuk mengumpulkan data dalam penelitian. Adapun instrumen penelitian tersebut berupa tes uraian. Dalam tes uraian tersebut murid melakukan kegiatan dengan cara mendengarkan lagu Bunda karya Melly Goeslow, kemudian siswa membuat cerpen dari lagu tersebut

\section{G. Teknik Analisa Data}

Untuk mengetahui keefektipan suatu media dalam kegiatan pembelajaran perlu diadakan analisa data. Pada penelitian ini menggunakan teknik analisis deskriptif kuantitatif, yaitu suatu metode penelitian yang bersifat menggambarkan kenyataan atau fakta sesuai dengan data yang diperoleh dengan tujuan untuk mengetahui prestasi belajar yang dicapai siswa, juga untuk memperoleh respon siswa terhadap 
kegiatan pembelajaran serta aktivitas siswa selama proses pembelajaran.

\section{Teknik Analisis Data Kuantitatif}

Analisis kuantitatif dipakai untuk menganalisis data kuantitatif.

Untuk mengetahui nilai rata-rata kelas dengan mengunakan penilaian rentang nilai maka menggunakan rumus berikut.

Nilai rata-rata $=\frac{\text { jumlah nilai seluruh siswa }}{\text { jumlah siswa }}$

\section{H. Validitas dan Reliabilitas Data}

\section{Validitas}

Validitas merupakan derajat yang menunjukkan suatu tes mengukur apa yang hendak diukur. Ada lima kriteria yang dipandang paling tepat untuk diterapkan pada penelitian tindakan yang bersifat transformatif. Kelima kriteria validitas tersebut adalah validitas demokratik, validitas hasil, validitas proses, validitas katalik, dan validitas dialogis. Dalam penelitian ini, validitas yang akan digunakan yaitu validitas demokratik, validitas proses, dan validitas hasil.

\section{Reliabilitas}

Salah satu cara untuk mengetahui sejauh mana data yang dikumpulkan reliable adalah dengan mempercayai penilaian peneliti itu sendiri. Reliabilitas dalam penelitian ini diwujudkan dengan penyajian data asli penelitian yang meliputi transkip wawancara, catatan lapangan, angket, foto, dan dokumentasi tugas siswa.

\section{Kriteria Keberhasilan Tindakan}

\section{Kriteria Keberhasilan}

keberhasilan penelitian tindakan di tandai dengan adanya perubahan menuju arah perbaikan. Indikator keberhasilan dalam penelitian tindakan kelas ini di kelompokkan menjadi dua aspek yaitu:

a. Indikator keberhasilan proses, di lihat dari tindak belajar atau perkembangan proses pembelajaran di kelas yaitu sebgai berikut:
1) Proses pembelajaran dilaksanakan dengan menarik dan menyenangkan

2) Siswa aktif berperan serta selama proses pembelajaran berlangsung

3) Terjadi peningkatan minat siswa terhadap pembelajaran menulis cerpen.

b. Indikator keberhasilan hasil, di lihat dari kriteria keberhasilan penelitian tindakan kelas ini di dasarkan pada keberhasilan produk. Keberhasilan produk didasarkan atas keberhasilan siswa dalam praktik menulis cerpen dengan media lagu. Kriteria keberhasilan praktik menulis cerpen dengan lagu adalah siswa dapat membuat cerpen dengan memperhatikan diksi, gaya bahasa, kesesuaian judul, tema dan isi dan makna dengan nilai keseluruhan di atas nilai ketuntasan minimal yakni 70 .

\section{HASIL PENELITIAN DAN PEMBAHASAN}

Dalam bab ini akan diuraikan tentang deskripsi hasil penelitian dan pembahasannya. Hasil penelitian yang akan diuraikan secara garis besar adalah informasi kemampuan awal siswa dalam menulis cerpen, pelaksanaan tindakan kelas persiklus, dan peningkatan kemampuan menulis cerpen dengan menggunakan media lagu "Elegi Esok Pagi" ciptaan Ebid G Ade. Pembahasan merupakan uraian hasil analisis informasi kemampuan awal siswa dalam menulis cerpen, pelaksanaan tindakan kelas persiklus, dan peningkatan kemampuan siswa dalam menulis cerpen dengan menggunakan media lagu "Elegi Esok Pagi” ciptaan Ebid G Ade.

\section{A. Hasil Penelitian}

Penelitian tindakan kelas yang dilakukan dengan menggunakan media lagu Bunda dalam pembelajaran menulis cerpen dilakukan secara bertahap. Kegiatan dimulai dengan penyusunan rencana tindakan, dilanjutkan dengan implementasi tindakan, pengamatan, dan refleksi. Hal-hal yang diperoleh sebagai hasil 
penelitian tindakan kelas akan diungkapkan di bawah ini.

Alat ukur yang digunakan untuk mengetahui peningkatan kemampuan menulis cerpen dalam penelitian ini adalah dengan tes. Dalam penelitian tindakan kelas ini akan disajikan peningkatan hasil tes menulis cerpen pretes hingga akhir siklus II. Rangkuman peningkatan hasil penelitian dapat dilihat pada tabel berikut.

Tabel 3.5 Peningkatan Rata-rata Pretes ke Siklus I dan Siklus II Kemampuan Siswa dalam Menulis Cerpen

\begin{tabular}{|l|c|c|c|}
\hline & Pretes & Siklus I & Siklus II \\
\hline $\begin{array}{l}\text { Jumlah } \\
\text { skor }\end{array}$ & 1150 & 2000 & 3000 \\
\hline $\begin{array}{l}\text { Rata-rata } \\
\text { hitung }\end{array}$ & 33,8 & 58,8 & 88,2 \\
\hline
\end{tabular}

Dari tabel di atas dapat diketahui peningkatan skor tes kemampuan menulis cerpen siswa dari sebelum tindakan sampai akhir tindakan (Siklus II). Nilai rata-rata hitung pretes 33,8 dan pada akhir siklus I nilai rata-rata hitung cerpen siswa menjadi 58,8. Jadi, kemampuan siswa dalam menulis cerpen mengalami kenaikan sebesar 25 .

Dari tabel diatas juga diperoleh data peningkatan skor rata-rata pretes ke siklus II kemampuan siswa dalam menulis cerpen. Hasil tes menunjukkan skor rata-rata hitung pretes cerpen siswa sebesar 33,8.

Di akhir siklus II skor rata-rata hitung cerpen siswa mengalami peningkatan yaitu menjadi 88,2. Jadi, peningkatan kemampuan siswa dalam menulis cerpen dari pretes hingga siklus II meningkat sebesar 54,4.

\section{B. Pembahasan}

\section{Informasi Awal Kemampuan siswa dalam Menulis Cerpen}

Berdasarkan data informasi awal yang diperoleh, kemampuan siswa dalam apresiasi cerpen khususnya menulis cerpen belum dilaksanakan secara maksimal. Dari hasil wawancara dengan guru, dalam kegiatan pembelajaran menulis cerpen. Guru belum menemukan strategi atau media pembelajaran yang tepat. Oleh karena itu, dengan pembelajaran menulis cerpen, siswa biasanya langsung disuruh menulis cerpen dengan tema tertentu tanpa menggunakan sarana pendukung yang dapat membantu proses menulis cerpen. Akibatnya, cerpen hasil karya siswa kurang memuaskan.

Dari tabel di atas diperoleh data tentang kemampuan awal siswa dalam menulis cerpen. Jumlah rata-rata hitung yang diperoleh siswa dari keseluruhan aspek yang dinilai adalah 33,8 atau jika dipersentasekan berjumlah 33,8\%. Dari hasil pretes ini dapat dikatakan bahwa kemampuan siswa kelas XI SMA Swasta Nasional Namotrasi dalam menulis cerpen berkategori kurang. Skor rata-rata aspek yang diamati dalam cerpen siswa belum mencapai nilai ketuntasan minimal yakni 75 .

Melihat kondisi tersebut, kegiatan praktik menulis cerpen di sekolah perlu dilakukan perbaikan-perbaikan. Salah satu langkah yang dapat diambil guru adalah pengembangan variasi pembelajaran dan penggunaan media atau cara pembelajaran yang tepat agar apresiasi siswa terhadap sastra tumbuh dengan baik. Melalui penggunaan media lagu "Bunda" ini, kualitas pembelajaran menulis cerpen dapat diangkatkan.

\section{Pelaksaan Tindakan Kelas Menulis Cerpen dengan Menggunakan Media Lagu "Elegi Esok Pagi" dalam Meningkatkan Kemampuan Siswa}

Pelaksanaan pembelajaran dengan menggunakan media lagu "Bunda" yang telah diterapkan dalam dua siklus, memfokuskan pada bentuk kegiatan menulis cerpen. Untuk mencapai hasil yang maksimal, guru dituntut untuk selalu memperhatikan seluruh siswa dalam praktik menulis cerpen dengan menggunakan media lagu "Bunda". Mulai dari mendengarkan lagu, mengingat sosok seorang Ibu, menuangkan ide-ide dan imajinasi 
selanjutnya, siswa mengembangkan lagu "Bunda" tersebut menjadi sebuah cerpen.

Berdasarkan hasil kerja siswa dari pretes hingga siklus II kemampuan menulis cerpen siswa mengalami peningkatan yang cukup signifikan.

\section{KESIMPULAN DAN SARAN}

\section{A. Kesimpulan}

Sesuai dengan batasan masalah di atas, penelitian ini menyatakan bahwa penggunaan media Lagu "Elegi Esok Pagi " dalam pemebelajaran sastra dapat meningkatkan kemampuan menulis cerpen siswa kelas XI SMA Swasta Nasional Namotrasi

\section{B. Saran}

Berdasarkan kesimpulan dan hasil penelitian yang telah dikemukakan di atas, saran untuk penelitian ini adalah sebagai berikut.

1. Bagi guru Bahasa Indonesia

Menggunakan media pembelajaran yang bervariasi dalam proses pembelajaran khususnya dalam apresiai sastra. Salah satu media pembelajaran ang dapat digunakan dalam pembelajaran apresiasi sastra khususnya pembelajaran menulis cerpen adalah media Lagu "Elegi Esok Pagi "

2. Bagi siswa

Kemampuan menulis cerpen yang sudah baik yang telah dicapai harus dipertahankan dan terus dikembangkan karena bukan tidak mngkin kelak ada salah seorang dari kalian yang menjadi seorang jurnal atau penulis.

3. Bagi pihak sekolah

Pihak sekolah harus lebih meninjau kembali kelengkapan sarana dan prasarana pembelajaran serta meningkatkan penggunaannya, sehingga akan mempermudah guru dalam merencanakan pembelajaran dengan menggunakan media yang bervariasi dan menarik.

\section{DAFTAR PUSTAKA}

Arikunto, Suharsimi. 2006. Penelitian Tindakan Kelas. Jakarta : Bumi Aksara

Arsyad, Azhar. 2003. Media Pembelajaran. Jakarta : Pt. Raja Grafindo Persada.

Depdiknas. 1994. Petunjuk Pelaksanaan Proses Belajar Mengajar.

\section{Kamus Besar Bahasa} Indonesia. Jakarta : Balai Pustaka.

Kokasih. E. 2008. Apresiasi Sastra Indonesia. Jakarta: Nobel Edumedia

Mukhlis, Abdul (Ed). 2000. Penelitian Tindakan Kelas. Makalah Panitia Pelatihan Penulisan Karya Ilmiah Untuk Guru-guru se-kabupaten Tuban.

Nurgintoro, Burhan. 2007. Teori Pengkajian Fiksi. Yogyakarta : Gadjah mada University Press.

Purba, Antilan. 2001. Sastra Indonesia Kontemporer. Medan : USU Press.

Sadiman, Arief, dkk. 2002. Media Pendidikan : pengertian Perkembangan dan Pemanfaatannya. Jakarta : Raja Grafindo Pustaka.

Sugiartik, Titik. 1997. Motivasi Belajar. Jakarta : Cerdas Pustaka.

Stanton, Robert. 2007. Teori Fiksi. Yogyakarta : Pustaka Pelajar

Tarigan, Henry Guntur. Prinsip - prinsip Dasar Sastra. Bandung : Angkasa. 
.2008. Menulis Sebagai Suatu Keterampilan Berbahasa. Bandung : Angkasa.

Van Hoeve, Ensiklopedia Indonesia. Jakarta : PT. Ichtiar Baru.

Widyamartaya, A. 2002. Seni Menuangkan Gagasan. Yogyakarta : Kanisius

Wiyanto, Asul. 2005. Kesusastraan Sekolah Penunjang Pembelajaran Bahasa Indonesia SMP dan SMA. Jakarta : Grasindo. 